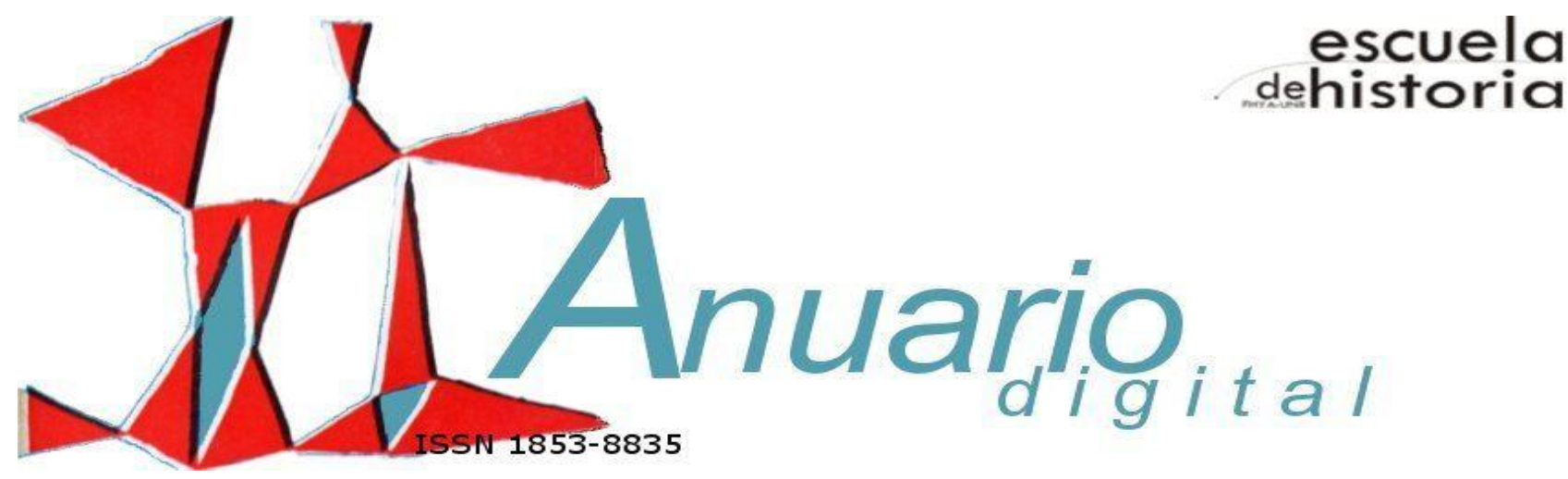

\title{
Claudio Sánchez-Albornoz, profesor de la Universidad Nacional del Litoral (Rosario) (1952-1956)
}

Claudio Sánchez-Albornoz, professor at the Universidad Nacional del Litoral (Rosario)

(1952-1956)

MARTÍN F. RÍOS SALOMA*

(Universidad Nacional Autónoma de México); México

riosmartin76@gmail.com

RESUMEN

En el presente trabajo se analizan los factores de orden histórico, institucional y personal que permitieron la incorporación del medievalista español Claudio Sánchez-Albornoz a la Universidad Nacional del Litoral, subrayando el hecho de que los años de docencia en la ciudad de Rosario coincidieron con un momento intelectual sumamente fecundo y con los años en los que se redactó la obra cumbre del madrileño España, un enigma histórico. En este sentido, ha sido posible reconstruir la cronología de la elaboración del libro y constatar los cercanos vínculos intelectuales de Sánchez-Albornoz con la historiografía francesa, en particular

\footnotetext{
* Investigador Titular "B", Tiempo Completo; Instituto de Investigaciones Históricas, Universidad Nacional Autónoma de México.
} 


\section{Claudio Sánchez-Albornoz, profesor de la Universidad Nacional del Litoral (Rosario)1952-1956}

con los aportes de Fernand Braudel. Ello muestra, en última instancia, la voluntad del sexagenario profesor de mantenerse permanentemente actualizado y de participar de los grandes debates intelectuales de su tiempo.

Palabras clave: Argentina; Edad Media; España; Historiografía; Sánchez-Albornoz.

ABSTRACT

In the present paper we analyze the factors of historical, institutional and personal order that allowed the incorporation of the Spanish medievalist Claudio Sánchez-Albornoz to the National University of the Litoral. We underlining the fact that the years of teaching in the city of Rosario coincided with a intellectual moment extremely fruitful and with the years in which the masterpiece of Sánchez-Albornoz was written: España, un enigma histórico. In this sense, it has been possible to reconstruct the chronology of the elaboration of the book and to verify the close intellectual links between Sánchez-Albornoz and French historiography, in particular with the contributions of Fernand Braudel. This work shows, in the last instance, the wish of the sexagenarian teacher to keep himself constantly updated and to participate in the great intellectual debates of his time.

Keywords: Argentina;Middle Ages;Historiography; Sánchez-Albornoz; Spain.

\section{Una encrucijada vital: $1952-1956 .^{1}$}

El 11 de agosto de 1952 el Delegado Interventor de la Facultad de Filosofía y Letras de la Universidad Nacional del Litoral con sede en la ciudad de Rosario, Argentina, firmó la resolución número 658 en la que resolvía, "considerando de urgente necesidad, dado lo avanzado del curso lectivo", designar como profesor interino del curso de "Historia de España" a partir del 30 de julio pasado en sustitución del doctor Ismael Sánchez Bella, quien había renunciado al curso en aquella fecha. El nombramiento de Sánchez-Albornoz obedecía a que era "una personalidad de reconocido prestigio docente" y se mantendría vigente hasta el 1 de mayo de 1956, año en que el propio don Claudio renunció a su puesto.

\footnotetext{
${ }^{1}$ El presente artículo forma parte del proyecto "Claudio Sánchez-Albornoz (1893-1984): una biografía intelectual”, investigación apoyada por el programa PASPA-DGAPA, UNAM. Agradezco a los profesores Ariel Guiance, Ma. Cristina Viano, Mariano Otero y Leonardo Funes, así como a sus respectivos centros de investigación, todas las facilidades brindadas para poder llevar a cabo esta investigación. Vaya un reconocimiento especial a los profesores Juan Hernández, Alejandro Vila, Alba Acevedo, Silvia Arroñada y Mercedes Temperley por haber orientado mis pasos en busca de las huellas de Sánchez-Albornoz en tierras argentinas.

2 Universidad Nacional del Litoral. Facultad de Filosofía, Letras y Ciencias de la Educación. Resolución Nº58. Rosario, 11 de agosto de 1952.
}

155

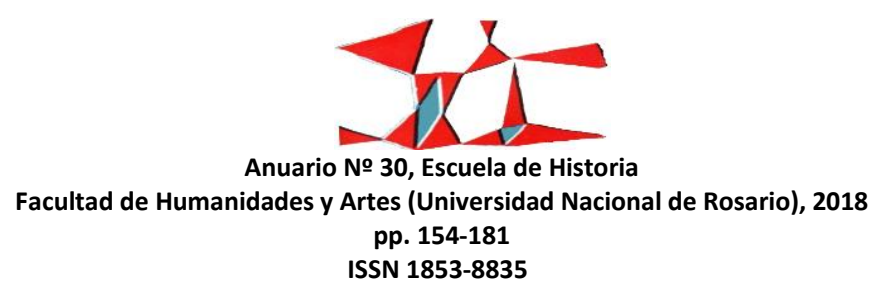


La mayoría de las semblanzas biográficas que se han realizado sobre la figura de Sánchez-Albornoz omiten estos cuatro años de docencia en la universidad de Rosario y su paso por la ciudad del Paraná queda silenciado frente a los años en los que el célebre medievalista español impartió docencia en la Universidad de Valladolid (1919-1920), la Universidad Central de Madrid (1920-1936), la Universidad de Burdeos (19371940), la Universidad Nacional de Cuyo (Mendoza) (1940-1942) y la Universidad de Buenos Aires (19421982). ${ }^{3}$ Sin embargo, el cuatrienio que se extiende entre 1952 y 1956 fue uno de los más importantes del quien fuera también Rector de la Universidad Central de Madrid durante la Segunda República, pues fue en esos años cuando puso en marcha uno de sus proyecto intelectuales más ambiciosos: la preparación de la respuesta a las propuestas de Américo Castro contenidas en el libro España en su historia y que se acabaría materializando en la realización de España, un enigma histórico, que saldría a la luz, precisamente, en $1956 .{ }^{4}$

Por otra parte, en el ámbito personal, los años de docencia en Rosario coinciden con una aceptación, por parte del madrileño, de la realidad de las cosas, es decir, del hecho de que la vuelta a la patria anhelada era difícil y de que el exilio sería mucho más largo de lo que había previsto en su momento. Esa aceptación de los hechos se tradujo el abandono de una situación que podría calificarse de temporal, en la adquisición de un apartamento en la zona de la Recoleta y en la celebración de un segundo matrimonio con la argentina Delia Casco. ${ }^{5}$ De esta suerte, a través de los textos autobiográficos que Sánchez-Albornoz publicó en

\footnotetext{
3 Una de las pocas referencias al paso de Sánchez-Albornoz por la Universidad Nacional del Litoral: "Sánchez-Albornoz y Menduiña, Claudio"; en: Ignacio Peiró Martín y Gonzalo Pasamar Alzuria, (eds.); Diccionario Akal de historiadores españoles contemporáneos (1840-1980); Akal; Madrid; 2002; pp. 565-568. He realizado un exhaustivo balance historiográfico en torno a la vida y obra de Claudio Sánchez-Albornoz en un artículo de inminente aparición: Ríos Saloma, Martín; “De Europa a América: Claudio Sánchez-Albornoz y la fundación de los Cuadernos de Historia de España"; en Medievalismo, № 28; Sociedad Española de Estudios Medievales; Madrid; 2018. En prensa. Entre los múltiples trabajos que han abordado la obra del medievalista español destaco tan sólo algunos ejemplos: AA. VV; Sánchez-Albornoz a debate. Homenaje de la Universidad de Valladolid con motivo de su centenario; Universidad de Valladolid; Valladolid; 1993; Cabeza de Sánchez-Albornoz, Sonsoles; Semblanza histórico política de Claudio Sánchez-Albornoz; Fundación Universitaria Española-Diputación Provincial de León; León; 1992; Martín, José Luis; "Claudio Sánchez-Albornoz (1893-1984)"; en J. Aurell y F. Crosas (eds.); Rewriting the Middle Ages in the Twenthiet Century; Brépols; Turnhout; 2005; pp. 149-170; Pastor de Togneri, Reyna; "Claudio Sánchez-Albornoz y sus claves de la historia medieval de España”; en E. Sarasa y E. Serrano (coords.); Historiadores de la España medieval y moderna, número especial de la Revista de historia Jerónimo de Zurita; N 73; CSIC; Zaragoza; 1998; pp. 117131; Pérez-Prendes y Muñoz de Arraco, José Manuel; "Semblanza y obra de don Claudio Sánchez-Albornoz"; En la España medieval; № 5; Facultad de Geografía e Historia; Madrid; 1986; pp. 19-52.

${ }^{4}$ Castro, Américo, España en su historia: cristianos, moros y judios; Losada; Buenos Aires; 1948; Sánchez-Albornoz, Claudio; España, un enigma histórico 2 vols.; Sudamericana; Buenos Aires; 1956.

${ }^{5}$ La primera mujer de Sánchez-Albornoz, Concepción Aboín, a quien había conocido durante su magisterio vallisoletano, había muerto en 1932. Sánchez-Albornoz, Claudio; Mis tres primeros ensayos históricos; Universidad de Valladolid; Valladolid; 1976; p. 7; Grassotti, Hilda; "Historia de un historiador"; en Homenaje al profesor Claudio Sánchez Albornoz, Universidad de Buenos Aires; Buenos Aires; 1964; pp. 13-27; p. 17 y Principado de Asturias; Homenaje de Asturias a Claudio Sánchez-Albornoz; Caja de Ahorros de Asturias; Oviedo; 1980; p. 23.
}

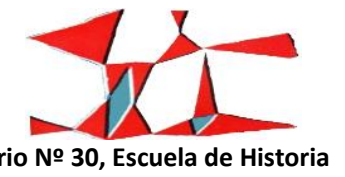

Facultad de Humanidades y Artes (Universidad Nacional de Rosario), 2018

pp. 154-181

ISSN 1853-8835 


\section{Claudio Sánchez-Albornoz, profesor de la Universidad Nacional del Litoral (Rosario)1952-1956}

periódicos de Argentina y España a lo largo de la década de 1970, sabemos que en marzo de 1944 abandonó el hotel en el que se había alojado tras su arribo de Mendoza en julio de 1942 y se instaló en el piso de la calle de Tomás Anchorena, departamento que, según sus propias palaras "iba a servir[le] de hogar al contraer segundas nupcias con una argentina". ${ }^{6}$ Posteriormente, gracias a la Ley de propiedad horizontal promovida por el gobierno de Perón (1948), ${ }^{7}$ Sánchez-Albornoz tuvo oportunidad de hacerse con la propiedad del piso que alquilaba desde 1944 y, según sus propios recuerdos, lo compró en 1953 "por 44000 pesos a pagar en cuatro años". ${ }^{8}$ Si hacemos las cuentas, resulta que esos cuatro años coinciden con su paso por la Universidad Nacional del Litoral y seguramente los ingresos extra le sirvieron para cumplir sus compromisos financieros.

De lo expuesto hasta aquí puede concluirse que el cuatrienio 1952-1956 resultó fundamental en la vida de Sánchez-Albornoz tanto en lo académico como en lo personal y que el paso por Rosario, lejos de ser anecdótico, significó la posibilidad de integrar a la planta docente de aquella institución argentina a uno de los intelectuales españoles más reconocidos de la primera mitad del siglo XX y para éste, el inicio de una nueva etapa vital caracterizada por su afincamiento en la República argentina. En las próximas páginas analizaremos con detalle este momento vital en el marco de la trayectoria intelectual de Sánchez-Albornoz.

\section{De Madrid a Rosario}

Claudio Sánchez-Albornoz nació en Madrid en 1894 en el seno de una familia terrateniente originaria de Ávila, lo que le permitió contar con el capital económico, social, político y cultural para cursar los estudios de Filosofía y Letras en la Universidad Central de Madrid, por la que se doctoró en 1914 con la tesis "La potestad real en Castilla". ${ }^{9}$ En 1915 ingresó como archivero al Archivo Histórico Nacional y en 1918 obtuvo

\footnotetext{
6 "La noche última que dormí en el hotel de Buenos Aires donde me alojaba antes de instalarme en el departamento que iba a servirme de hogar al contraer segundas nupcias con una argentina, tuve la certeza de que vino a despedirse de mi el espíritu de mi primera mujer española, la santa madre de mis hijos". Sánchez-Albornoz, Claudio, "El mundo de los espíritus. Una venganza de Picasso"; en Sánchez-Albornoz, Claudio; Del ayer y del hoy de España; Planeta; Madrid, 1980; pp. 218-222, p. 219.

7 Ballent, Anahi; Las huellas de la política, Vivienda, ciudad, peronismo, Universidad de Quilmes-Prometeo; Buenos Aires; 2005; en especial el capítulo II pp. 55-96; Pilcic, Talía; "La distribución del bienestar en la Argentina Peronista. La ley de Propiedad Horizontal y su impacto en la ciudad de Mar del Plata"; en Segundas Jornadas Nacionales de Historia Social, 13, 14 y 15 de mayo de 2009 , La Falda, Córdoba. Memoria Académica; Universidad de la Plata; La Plata; 2009 Disponible en: http://www.memoria.fahce.unlp.edu.ar/trab eventos/ev.9748/ev.9748.pdf.

[Consultado el 13 de septiembre de 2018]

8 Sánchez-Albornoz; Claudio; Todavía. Otra vez de ayer y de hoy; Planeta; Barcelona, 1982; p. 143. En otro texto escribe: "En 1954 compré mi departamento en lo que vale hoy una cajetilla de pitillos". Sánchez-Albornoz, Claudio; Confidencias, Espasa-Calpe, Madrid, 1979, pp. 167-170, p 167.

9 Sánchez-Albornoz, Claudio; "La potestad real y los señoríos en Asturias, León y Castilla"; en Revista de Archivos Bibliotecas y Museos; N²1; Madrid; 1914; pp. 263-293.
}

157

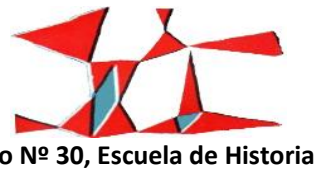

Facultad de Humanidades y Artes (Universidad Nacional de Rosario), 2018

pp. 154-181

ISSN 1853-8835 
por posición la Cátedra de Historia de España en la Universidad de Barcelona. ${ }^{10}$ De alma castellana, SánchezAlbornoz pidió su traslado a la Universidad de Valladolid -ciudad en la que conoció a su primera mujer, Concepción Aboín- y en 1920 se trasladó a la Universidad Central de Madrid donde obtuvo por oposición la Cátedra de Historia Antigua y Media de España vacante por la muerte de su maestro e historiador de las instituciones Eduardo de Hinojosa. En 1923 se hizo con el Premio Nacional Covadonga, convocado por las Academias de Historia y Española para conmemorar el centenario de la batalla de Covadonga y ello le mereció su ingreso a la Real Academia de la Historia, sitial del que tomó posesión el 28 de febrero de 1926, convirtiéndose a la sazón en el académico más joven de la corporación con tan solo 32 años. ${ }^{11}$

Al advenimiento de la Segunda República, Sánchez-Albornoz se convirtió en diputado por la provincia de Ávila y ejerció diversos cargos, entre los que destaca el de Rector de la Universidad Central en el bienio 1932-1934. Fue en el desempeño de este cargo que el madrileño viajó por vez primera a Argentina, invitado por la Institución Cultural Española, en agosto de 1933 e impartió una serie de conferencias tanto en la capital argentina como en la ciudad de la Plata en el marco de las actividades de intercambio y cooperación que la Institución Cultural Española había desarrollado desde los primeros años del siglo XX en colaboración con la Junta de Ampliación de Estudios. ${ }^{12}$ A la vuelta de su viaje al país Latinoamericano Sánchez-Albornoz ocupó distintos cargos políticos hasta que en mayo de 1936 fue designado como embajador del gobierno republicano ante Portugal. La adhesión del gobierno Salazar al alzamiento militar de Franco hizo insostenible la situación del embajador republicano y en octubre del mismo año huyó a Francia, instalándose a la postre en la Universidad de Burdeos con el apoyo del hispanista Georges Cirot y de otros importantes medievalistas como Marc Bloch o Louis Halphen, quienes firmaron sendas recomendaciones para que la Fundación Rockefeller de Nueva York becase al profesor español durante su estadía francesa.

\footnotetext{
${ }^{10}$ El madrileño recuerda la celebración de sus oposiciones en el texto “Oposiciones”; en Sánchez-Albornoz, Claudio, Todavía. Otra vez de ayer y de hoy; op cit., pp. 94-97.

${ }^{11}$ Real Academia de la Historia, "Acta de la Junta Pública del domingo 28 de febrero de 1926 con motivo de la recepción de Claudio Sánchez-Albornoz"; en Boletín de la Real Academia de la Historia; N LXXXVIII; Real Academia de la Historia; Madrid; 1926; pp. 376378.

12 Las conferencias fueron: "La España de hoy vista por un historiador", pronunciada en el Instituto Popular de Conferencias; "La mujer española hace mil años", impartida en el Jockey Club de Buenos Aires y "La Edad Media y la empresa de América", pronunciada en la Universidad de la Plata. La información se ha obtenido cruzando datos de los distintos textos autobiográficos editados por don Claudio en libros misceláneos.
} 


\section{Claudio Sánchez-Albornoz, profesor de la Universidad Nacional del Litoral (Rosario)1952-1956}

A pesar de que el gobierno mexicano había cursado una invitación a Sánchez-Albornoz para que éste se instalara en el país norteamericano y se incorporara a la planta docente de la Universidad Nacional Autónoma de México, el antiguo embajador prefirió continuar con sus actividades en la universidad bordelesa y en ella preparó el manuscrito de uno de sus textos fundamentales: En torno a los orígenes del feudalismo que, sin embargo, no llegó a publicar en la institución gala. En junio de 1940, tras la ocupación nazi, se cursaron órdenes de detener al antiguo Académico de la Historia y remitirlo a España donde sería juzgado. Gracias al apoyo de una amiga -cuyo nombre ha quedado silenciado- Sánchez-Albornoz escapó hacia al Francia Libre y dese ahí contactó con diversas instituciones para buscar un refugio académico e intelectual. Rafael Vehelis, a la sazón director de la Institución Cultural Española, propuso al madrileño desplazarse a Buenos Aires y frente al silencio o negativa de otras instituciones, el otrora rector de la Universidad Central se vio obligado a optar por la opción argentina y tras un periplo que le llevó por distintos puertos europeos, africanos y americanos, desembarcó en Buenos Aires por segunda vez el 3 de diciembre de $1940 .{ }^{13}$

Como bien ha explicado Ariel Guiance, los aires en la ciudad porteña no era proclives al asentamiento de un liberal de la talla política de Sánchez-Albornoz, por lo que distintas circunstancias confluyeron para Sánchez-Alborno fuese contratado por la Facultad de Filosofía y Letras de la Universidad Nacional de Cuyo, en Mendoza. ${ }^{14}$ De esta suerte, el madrileño, que a la sazón contaba con 46 años, permaneció unos pocos días hospedado en un hotel de la céntrica calle Bartolomé Mitre, se entrevistó con algunas personas que había conocido en su viaje anterior, asistió a misa en la iglesia de San Miguel ${ }^{15}$ y tomó el tren rumbo a Mendoza acompañado de sus notas, del manuscrito de la obra En torno a los orígenes del feudalismo, de los cinco volúmenes del estudio "Instituciones sociales y políticas del reino de Asturias" con el que había conquistado el premio Covadonga y con el apoyo financiero de la Fundación Rockefeller que había aceptado trasladar la beca concedida al país sudamericano. ${ }^{16}$

\footnotetext{
13 Para todas estas informaciones y su correspondiente apoyatura documental remito al lector al artículo Ríos Saloma, Martín; “De Europa a América: Claudio Sánchez-Albornoz y la fundación de los Cuadernos de Historia de España"; op. cit.

${ }^{14}$ Guiance, Ariel; "La historiografía española y el medievalismo americano: Sánchez-Albornoz, Américo Castro y la construcción de la identidad nacional a través de la Edad Media”; en A. Guiance (dir.); La influencia de la historiografía española en la producción americana; Marcial Pons - Instituto de Historia Simancas; Madrid; 2011; pp. 25-58.

15 Sánchez-Albornoz, Claudio, Postrimerías. Del pasado hacia el futuro; Planeta; Barcelona; 1981; pp. 95-96.

16 López Sánchez, José María; Los refugios de la derrota. El exilio científico e intelectual republicano de 1939; Consejo Superior de Investigaciones Científicas; Madrid; 2013; pp. 45-52.
}

159

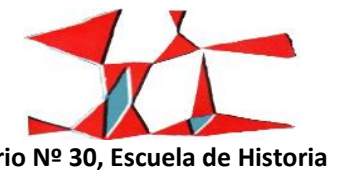

Facultad de Humanidades y Artes (Universidad Nacional de Rosario), 2018

pp. 154-181

ISSN 1853-8835 
El día 12 de diciembre el célebre medievalista arribó a la ciudad andina, ${ }^{17}$ se instaló en el céntrico Hotel Plaza y fue a saludar al Rector, quien le recriminó que se hubiese presentado pocos días antes del inicio de las vacaciones estivales sin considerar la odisea que el viajero había realizado. El Rector le propuso realizar un ciclo de conferencias, pero pronto desistió por la más que probable falta de público, sugiriéndole a continuación "darse a conocer" escribiendo "algo para la prensa". Albornoz, libre de toda carga, se puso a la labor y el $1^{\circ}$ de enero de 1941 el diario Los Andes, el más importante de la región, publicó un artículo suyo intitulado Roosevelt y Carlomagno en el cual el medievalista reflexionaba sobre los acontecimientos de su presente y hacía una analogía entre el emperador medieval y el presidente norteamericano. Tal fue el éxito en esta labor periodística que Sánchez-Albornoz continuaría escribiendo con regularidad como columnista el diario andino hasta julio de 1941 en que el artículo "Gibraltar", en el que criticaba el intervencionismo de los ingleses en la economía argentina, desató el enojo de éstos y el periódico hubo de prescindir de sus colaboraciones. Estas columnas, a demás de permitirle "darse a conocer" en el medio local mendocino, le permitieron allegarse un ingreso que le "ayudaba a vivir materialmente, pues [...] no cobraba -afirma- en dólares, sino en pesos argentinos". ${ }^{18}$

El año y medio que vivió Sánchez-Albornoz en Mendoza fue sumamente fecundo. Adscrito al Instituto de Investigaciones Históricas de la Facultad de Filosofía y Letras, ${ }^{19}$ el madrileño impartió clases de forma regular y tomó a su cargo el curso de "Historia Medieval", el cual "se caracterizó por el tratamiento eminentemente científico del problema sobre los orígenes del feudalismo, fundado en un riguroso análisis heurístico". ${ }^{20}$ De igual manera, puso en práctica la modalidad del trabajo de seminario aprendida con Alphons Dospch durante su estancia en Viena (1927-1928), impartiendo un seminario sobre "La caballería franca y la caballería musulmana del siglo VIII", sustentado en los materiales con los que había elaborado el libro sobre el feudalismo. Finalmente, impartió diversas conferencias de extensión universitaria y trabajó en la puesta a punto de sus tres volúmenes sobre Los orígenes del feudalismo que le publicaría al cabo la Universidad de Cuyo en 1942 y los cuales le valdrían, a la postre, su ingreso como académico correspondiente del Institut de France (1947). ${ }^{21}$ Las memorias de la Facultad de Filosofía y Letras guardan un retrato vivaz de Sánchez-

\footnotetext{
17 Sánchez-Albornoz, Claudio; Toda vía. Otra vez de ayer y de hoy, op. cit., p. 126.

18 Sánchez-Albornoz, Claudio, Ensayos sobre historia de España; Siglo XXI; Madrid; 1973; p. 10.

19 Universidad Nacional de Cuyo; Memoria histórica de la Facultad de Filosofía y Letras (1939-1964); Universidad Nacional de CuyoFacultad de Filosofía y Letras; Mendoza; 1965, p. 145.

20 lbid., p. 365.

${ }^{21}$ Sánchez-Albornoz, Claudio; Los orígenes del feudalismo; 3 vols.; Universidad Nacional de Cuyo; Mendoza; 1942.
}

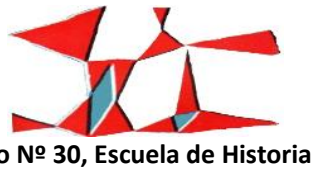




\section{Claudio Sánchez-Albornoz, profesor de la Universidad Nacional del Litoral (Rosario)1952-1956}

Albornoz que merece la pena reproducir, ya que es una de las pocas descripciones que se han conservado sobre nuestro personaje en el momento en que llegó a Argentina:

El arribo a Mendoza de [Sánchez-Albornoz] despertó enorme interés, porque se trataba de un estudioso cuya especialidad no se cultivaba en el país, por lo menos a nivel de la investigación histórica. Sus clases y conferencias atraían nutrido público de estudiantes y personas vinculadas al medio cultural de la ciudad. [...] En lo personal el Dr. Sánchez Albornoz vivía por entonces los años de su plenitud vital. En aquella Mendoza de 1940, de calles dormidas, se lo veía moverse con cierta bonhomía. Daba la impresión de un hombre fuera de ambiente y con demasiada carga cultural para una novel universidad. Entraba en el amplio patio de la Facultad de Facultad de Filosofía y Letras con el señorío de quien está habituado a los escenarios de claustros y cancillerías europeas. Caminaba sin prisa, aunque con soltura, y en los días de invierno llevaba una capa española que movía con una sabiduría elegante. Su cabello escaso y oscuro, que con discreción plegaba sobre una calvicie avanzada, enmarcaba un rostro español de tez blanca, ojos morunos, que él solía asociar con su apellido Albornoz, y cejas negras y espesas. Unos bigotes, también negros, centraban el semblante. Su rostro decía mucho, porque brillaba en él la inteligencia misma. Vestía unos trajes oscuros, negros o azules. ${ }^{22}$

Uno de los artículos que don Claudio escribió para Los Andes en el tiempo libre que le dejaban las clases, las conferencias y la revisión de sus tres volúmenes sobre Los orígenes del feudalismo, apareció en la edición dominical del 22 de junio de 1941. El texto se intitulaba "Acerca de la enseñanza de la Historia de España en Argentina" y resulta sumamente interesante para nuestro estudio pues el madrileño propuso en él, por vez primera, la necesidad de que América Latina conociera científicamente su pasado hispánico. Movido por un "reproche" que salía de su "alma enamorada de España", el autor, tras reconocer las virtudes y la solidez de las universidades argentinas, preguntaba a sus colegas: “¿por qué, profesores argentinos, en el variadísimo y rico -yo me atrevería a llamarle completo, si no fuese por lo que voy a decir- cuadro de vuestras enseñanzas habéis olvidado una disciplina: la historia de España?". ${ }^{23} \mathrm{El}$ antiguo académico de la historia comprendía que

\footnotetext{
22 Ibid., pp. 444-445. Citamos por esta última edición.

161

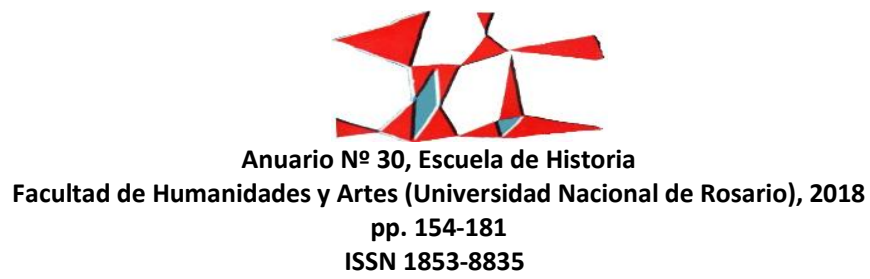

23 Sánchez-Albornoz, Claudio "Acerca de la enseñanza de la Historia de España en Argentina"; en Los Andes, Mendoza, 22 de junio de 1941. Reproducido en Sánchez-Albornoz, Claudio; De Carlomagno a Roosevelt; Emecé; Buenos Aires; 1943; pp. 183-189, p. 184. 
tras la independencia la joven nación argentina "volviese la espalda" a su propio pasado, "al pasado de España", pero no comprendía que pasado más de un siglo, siendo "la primera potencia hispana del continente americano" y dados que los argentinos eran correspondidos por España "en el amor y la devoción", éstos olvidasen su propia historia: "Os habéis dado con ímpetu -afirma- al estudio de la literatura y de lengua españolas Vuestros trabajos sobre ellas igualan a los trabajos de los estudiosos españoles. Y, sin embargo, seguís olvidando el pasado de España, vuestro propio pasado, y en ninguna universidad argentina se dicta un curso de Historia de España". ${ }^{24}$

El antiguo embajador entendía que en Argentina hubiese un interés por "los restos de las pobres culturas indígenas" y no reprochaba a etnólogos y antropólogos "ese culto a lo indígena", pero afirmaba categórico dirigiéndose al lector mendocino y argentino: "no es menor vuestro deber de estudiar la historia española, vuestra historia, y de enseñarla a vuestra mocedad". ${ }^{25}$ Para el estudioso de las instituciones feudales, los auténticos abuelos de los argentinos no eran "los indios" -o lo eran "en muy reducida proporción"- sino que éstos eran "de pura cepa hispana" y no habían hecho "pobres vasos de ruda cerámica o [...] toscos templos y primitivas esculturas", ${ }^{26}$ sino que habían construido una auténtica civilización entre cuyas manifestaciones se hallaban algunos de los más importantes ejemplos del arte occidental, desde la Cueva de Altamira, el alcázar de Toledo, la Alhambra o el Escorial. Y así, don Claudio se preguntaba cómo era posible que se pudiesen seguir en Mendoza cursos "de Historia de Francia o de historia de Inglaterra" y no se pudiese seguir "un curso de Historia de España. Y como en ella, en todas las universidades de la República". ${ }^{27}$ Sánchez-Albornoz terminaba su artículo lanzando a los mendocinos, a los argentinos y a los españoles residentes en la república austral una pregunta retórica que era, en realidad, una idea programática: “¿por qué no incluís entre vuestros planes de estudio una cátedra de la Historia de España, en la que la mocedad argentina aprenda la historia de los abuelos de San Martín, Rivadavia o Sarmiento? Españoles que vivís en estas tierras acogedoras argentinas, ¿̇por qué no colaboráis a la empresa de hacer conocer la historia española en las universidades que frecuentan vuestros hijos?" Y concluía, conciliador, deseando "[...] que en torno al nombre y la gloria de España se empiece a hacer la paz entre españoles". ${ }^{28}$

\footnotetext{
24 lbid., p. 184.

25 Ibid., p. 185.

26 lbid., p 185.

27 Ibid., p. 188.

28 lbid., p. 189.
} 


\section{Claudio Sánchez-Albornoz, profesor de la Universidad Nacional del Litoral (Rosario)1952-1956}

Ariel Guiance ha estudiado el ambiente político, cultural e intelectual en el que se insertó SánchezAlbornoz y el hecho de que el importante flujo migratorio español de finales del siglo XIX se tradujera en una redefinición de la identidad argentina y es en el marco de estos debates en el que deben entenderse las reflexiones del madrileño. ${ }^{29}$ Sería fácil pensar que el desconocimiento del mundo indígena americano por parte del medievalista es el que le llevó a lanzar una mirada despectiva hacia las culturas aborígenes y sus manifestaciones materiales, pero el asunto es mucho más complejo.

Cómo todos los españoles nacidos a finales del siglo XIX Sánchez-Albornoz se había formado en el marco de la historia nacional y compartía con el resto de sus coetáneos la idea de que España era una gran nación que había forjado un gran imperio en América y que había aportado a dicho continente una semilla civilizadora. Pero en tanto estudioso de la formación de las instituciones medievales peninsulares, el madrileño constató "con vista de ojos" la proyección de esas instituciones en América. Ciertamente, la Mendoza de 1940 por la que caminaba don Claudio no era la que había fundado Pedro del Castillo en 1561 en nombre del virrey del Perú Andrés Hurtado de Mendoza -la cual había sido destruida por terremoto a finales del siglo XIX-, pero encontraba en ella nombres, apellidos de ilustres familias locales, símbolos religiosos -el "Ave María" como emblema de la ciudad, por ejemplo- y elementos culturales originados en España muchos siglos atrás. Para decirlo de forma sencilla, la estancia en Mendoza permitió a SánchezAlbornoz mirar con detenimiento por vez primera a España desde la distancia y encontrar a España en América y por ello no es de extrañar que el antiguo embajador pusiese todos sus esfuerzos en fundar una Cátedra de Historia de España en el país que le acogía.

La oportunidad se presentó en junio de 1942 cuando deshizo los más de mil kilómetros que separaban la ciudad andina de la capital porteña y se instaló, por fin, el 15 de junio de dicho año en la Facultad de Filosofía y Letras de la Universidad de Buenos Aires gracias a las gestiones de Rafael Vehelis y Emilio Ravignani, decano de la mencionada Facultad. La UBA había creado para Sánchez-Albornoz el Instituto de Historia de la Cultura Española Medioeval y Moderna y la Cátedra de Historia de España en la que el madrileño ejercería su magisterio por más de cuarenta años y en la que editaría los Cuadernos de Historia de España. Seis años después de su instalación en la UBA, Sánchez-Albornoz podía ufanarse en el número IX (1948) de la revista de que existían para entonces tres nuevas cátedras de Historia de España: la de la "Facultad de Humanidades

${ }^{29}$ Guiance, op. cit.

163

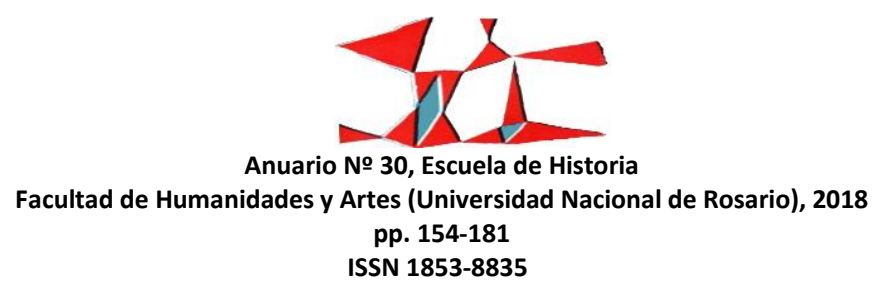


de la Universidad de La Plata, la del Instituto Nacional del Profesorado Secundario de Buenos Aires y la de la Facultad de Humanidades y Ciencias de Montevideo". ${ }^{30}$

La cuarta cátedra de Historia de España fue la de la Facultad de Filosofía, Letras y Educación de la Universidad Nacional del Litoral. No nos ha sido posible establecer con certitud el momento en el que se fundó dicha cátedra en aquella institución, pero si hemos podido determinar que, al menos desde el $1^{\circ}$ de marzo de 1951, estaba a cargo de Ismael Sánchez Bella, quien cobraba por su desempeño 1,800 pesos de aquellos años. ${ }^{31}$ Sánchez Bella (n. 1922), de tendencias conservadoras, afín al régimen franquista y a la postre destacado miembro del Opus Dei, había realizado los estudios de derecho en la Universidad de Valencia, había sido becario en 1943 del "Instituto Gonzalo Fernández de Oviedo" de Sevilla y se había doctorado en Historia del Derecho por la Universidad Central en 1948 con un trabajo sobre los Organismos administrativos de la Real Hacienda Indiana (1493-1605): (contribución al estudio del derecho indiano). Tras doctorarse, había obtenido por oposición celebrada el 18 de enero de 1949 la Cátedra de Historia del Derecho Español en la Universidad de la Laguna, de la que sin embargo se separó mediante excedencia para trasladarse a Rosario y ocuparse de la Cátedra de Historia de España en la institución argentina. ${ }^{32}$ Queda por estudiar porqué y cómo el flamante catedrático decidió trasladarse desde España hasta Rosario. Como quiera que fuese, ocupó su puesto en calidad de "adjunto interino", dado que la Facultad se encontraba imposibilitada para proveer a las cátedras de los correspondientes profesores titulares según lo reflejan distintos documentos administrativos. ${ }^{33}$

Sánchez Bella ejerció su actividad hasta el 2 de junio de 1952, fecha en que solicitó "una licencia sin goce de haberes por el término de un año" para volver -hoy lo sabemos- a España al ser nombrado ese mismo año profesor de la Universidad de Navarra, de la que llegaría a ser vicerrector en $1959 .{ }^{34}$ En esa coyuntura y

${ }^{30}$ Sánchez-Albornoz, Claudio; "Varia”; en Cuadernos de Historia de España; N 9; Instituto de Historia de España; Buenos Aires; $1948 ;$ p. 208.

31 Universidad Nacional del Litoral. Facultad de Filosofía, Letras y Ciencias de la Educación. Resolución N³67. Rosario, 30 de abril de 1951.

32 "Sánchez Bella, Ismael"; en: Ignacio Peiró Martín y Gonzalo Pasamar Alzuria, (eds.), Diccionario Akal de historiadores españoles contemporáneos (1840-1980), op. cit.; pp. 570-571.

33 Universidad Nacional del Litoral. Facultad de Filosofía, Letras y Ciencias de la Educación. Resolución N³66. Rosario, 30 de abril de 1951; Universidad Nacional del Litoral. Facultad de Filosofía, Letras y Ciencias de la Educación. Resolución N 543. Rosario, 20 de marzo de 1952.

34 Universidad Nacional del Litoral. Facultad de Filosofía, Letras y Ciencias de la Educación. Resolución N 658. Rosario, 11 de agosto de 1952. La información sobre la carrera académica de Sánchez Bella en "Sánchez Bella, Ismael"; en Diccionario de historiadores...; op. cit., p. 570. Durante su paso por la Universidad del Litoral, Sánchez Bella publicó un ensayo, en el que podían leerse juicios e ideas

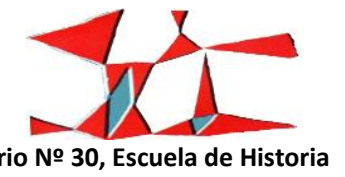




\section{Claudio Sánchez-Albornoz, profesor de la Universidad Nacional del Litoral (Rosario)1952-1956}

frente a la inminente reanudación de los cursos universitarios tras las vacaciones de invierno, Alberto Graziano, delegado interventor de la Facultad de Filosofía, Letras y Educación, resolvió designar a SánchezAlbornoz para encargarse de la mencionada cátedra -"correspondiente al segundo año del profesorado de historia" - mientras durara la licencia de Sánchez Bella, ${ }^{35}$ misma que se renovó en marzo del año siguiente. ${ }^{36}$ Como la licencia de Sánchez Bella concluyó el de 2 de junio de 1953 sin que el interesado se hubiese "reintegrado a sus funciones ni solicitado prórroga de la licencia", el mismo delegado interventor resolvió, con fecha de 27 de junio de 1953, "encargar interinamente a partir del 2 de junio de 1953, el dictado de la Cátedra de "historia de España" a Sánchez-Albornoz en atención a que la había dictado los años anteriores. 37

Tampoco es posible saber con la documentación que se ha conservado en Argentina de qué forma la Universidad del Litoral contactó al célebre medievalista para ocupar la cátedra. Lo que sí es posible afirmar, tanto por los escritos de don Claudio como por su epistolario con Emilio Sáez, es que su segundo matrimonio conllevó necesariamente nuevas responsabilidades económicas, que los pagos en la Universidad de Buenos Aires eran cuanto menos irregulares y que pasaba varios meses sin cobrar: "estoy sin cobrar desde enero escribía Sánchez-Albornoz a Sáez en marzo de 1949- porque no está aprobado [el presupuesto] y no lo estará hasta julio, con lo que estoy dividido". ${ }^{38}$ Podemos imaginar que la sensación de estrechez y precariedad era continuada al constatar que dos años después, en junio de 1952, compartía con su amigo las preocupaciones que le producía, aún, "el problema de la renovación de [su] contrato" en la Universidad de Buenos Aires. ${ }^{39}$

de clara tendencia conservadora como las siguientes: "Los hombres del 98 sienten los males nacionales, claman por su remedio con pasión, pero no saben buscarla donde podrán encontrarla. Finalmente, se abre paso en el siglo XX otra tendencia, importadora de la cultura germana, la más conocida, a través de la "Revista de Occidente" que realiza una amplia labor cultural valiosa, pero desviada también de la tradición española". Así se formó el clima de tensión insostenible que condujo a la violenta conmoción de 1936, cuyos resultados fueron en lo cultural el triunfo de la concepción tradicional, la verdaderamente nacional". Sánchez Bella, Ismael; La vida cultural española en los últimos diez años; Universidad Nacional del Litoral-Instituto Social; Santa Fe; 1952; pp. 18-19.

35 Universidad Nacional del Litoral. Facultad de Filosofía, Letras y Ciencias de la Educación. Resolución N 658 . Rosario, 11 de agosto de 1952.

${ }^{36}$ Universidad Nacional del Litoral. Facultad de Filosofía, Letras y Ciencias de la Educación. Resolución N 818. Rosario, 27 de marzo de 1953.

37 Universidad Nacional del Litoral. Facultad de Filosofía, Letras y Ciencias de la Educación. Resolución º 947. Rosario, 27 de junio de 1953.

38 Sáez, Carlos; "Epistolario de Claudio Sánchez-Albornoz y Emilio Sáez I (1948-1949)"; en Signo. Revista de historia de la cultura escrita; N 3; Universidad de Alcalá; Alcalá de Henares; 1996; pp. 205-220; p. 207. En junio del mismo año de 1949 , se quejaba con su interlocutor de que seguían sin pagarle y de que "andaba muy mal de plata". Ibid; p. 211.

39 Sáez, Carlos; "Epistolario de Claudio Sánchez-Albornoz y Emilio Sáez III (1952-1954)"; en Signo. Revista de historia de la cultura escrita; N 5; Universidad de Alcalá; Alcalá de Henares; 1998; pp. 203-215; p. 206.

165

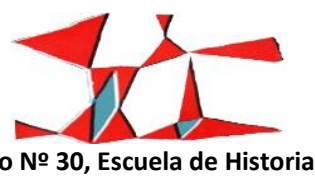

Facultad de Humanidades y Artes (Universidad Nacional de Rosario), 2018

pp. 154-181

ISSN 1853-8835 
Estos testimonios nos autorizan a pensar que Sánchez-Albornoz recibió con alegría el encargo pues le permitiría disfrutar de una situación económica un poco más holgada.

La alegría, sin embargo, duró poco. La propia documentación académico-administrativa conservada en Rosario muestra que, como todo profesor, el madrileño estaba obligado a dar clases varias horas al día para cubrir en una sola jornada las clases de una semana entera y debía asistir en dos fechas diferentes para tomar los exámenes del invierno y del verano, lo que cual era difícil conjugar con sus horarios docentes en Buenos Aires y con sus responsabilidades al frente del Instituto de Historia de España. De esta suerte, el 16 de octubre de 1952 escribía a Sáez con cierta molestia: “Aquí me tienen viajando a Rosario todas las semanas para hacer un curso de Historia de España. Afortunadamente acabo con el mes; por cierto, tendrán que buscar otro profesor porque tengo los huesos muy duros para hacer cinco horas de viaje de ida y otras cinco de vuelta y en un día todas las clases de la semana". ${ }^{40} \mathrm{~A}$ pesar de su queja, lo cierto es que el madrileño no renunció y en enero de 1954, cuando Sánchez-Albornoz estaba por cumplir 60 años, compartía de nuevo con Sáez la fatiga que le causaba la jornada rosarina: "tengo ya 60 años y la serie de clases que he de hacer para ir viviendo me cansan. Sobre todo los viajes a Rosario de $350 \mathrm{~km}$ y la serie de lecciones que he de hacer allí seguidas. Ahora están aquí de moda las clases de dos horas seguidas para que los profesores puedan atender sus diversas y alejadas tareas docentes, y confieso que esas dos horas seguidas son muy fatigosas para mí" ${ }^{41}$ A finales de aquel año, don Claudio se quejaba de nuevo de que los "viajes a Rosario" le impedían acabar su obra anti-Castro. ${ }^{42}$

A lo fatigoso del desplazamiento había que sumar un hecho importante que contribuía a aumentar el malestar: por circunstancias que no especifica la documentación académico-administrativa, a pesar de su

\footnotetext{
40 Sáez, "Epistolario [...] III (1952-1954)"; op. cit; p. 207. La documentación universitaria demuestra la carga docente de SánchezAlbornoz: Universidad Nacional del Litoral. Facultad de Filosofía, Letras y Ciencias de la Educación. Resolución N 942. Rosario, 19 de junio de 1953, en la que se le impone a Sánchez-Albornoz la obligación de fungir como tribunal en las "Mesas examinadoras" de la "Cátedra de Historia de España" los días 31 de julio y 14 de agosto del año en curso. Universidad Nacional del Litoral. Facultad de Filosofía, Letras y Ciencias de la Educación. Resolución N 1044. Rosario, 26 de septiembre de 1953, en la que se le impone a SánchezAlbornoz la obligación de fungir como tribunal en las "Mesas examinadoras" de la "Cátedra de Historia de España" los días 21 de noviembre y 19 de diciembre del año en curso. Universidad Nacional del Litoral. Facultad de Filosofía, Letras y Ciencias de la Educación. Resolución $N^{\circ}$ 1598. Rosario, 30 de mayo de 1955, en la que se le impone a Sánchez-Albornoz la obligación de fungir como tribunal en las "Mesas examinadoras" de la "Cátedra de Historia de España" los días $1^{\circ}$ y 22 de julio del año en curso. Universidad Nacional del Litoral. Facultad de Filosofía, Letras y Ciencias de la Educación. Resolución N 1677. Rosario, 16 de septiembre de 1955, en la que se le impone a Sánchez-Albornoz la obligación de fungir como tribunal en las "Mesas examinadoras" de la "Cátedra de Historia de España" los días 25 de noviembre y 16 de diciembre del año en curso.
}

${ }^{41}$ Sáez, "Epistolario [...] III (1952-1954)"; op. cit; p. 212.

42 Ibid., p. 214.

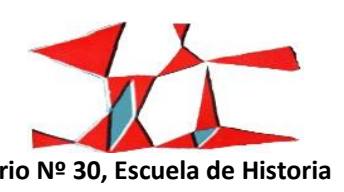




\section{Claudio Sánchez-Albornoz, profesor de la Universidad Nacional del Litoral (Rosario)1952-1956}

notable prestigio académico Sánchez-Albornoz se mantuvo durante todo el tiempo que tuvo a su cargo la cátedra de historia de España como profesor interino sin que se concretara un eventual contrato definitivo ${ }^{43}$ y, por si fuera poco y dada la propia naturaleza de su relación contractual con la Universidad, hubo, incluso, alguna ocasión en que por errores administrativos, no recibió los honorarios que le correspondían. ${ }^{44}$ Es lícito suponer que o bien la situación política por la que atravesaba el país, o bien la falta de recursos de la Universidad Nacional del Litoral o bien lo avanzado de la edad de Sánchez-Albornoz -o las tres juntas- fuesen causales de esta precariedad contractual. En cualquier caso, lo único que puede asegurarse con base en la documentación es que el 30 de abril de 1956 el delegado interventor, Juan Bruera, vio la renuncia presentada por Sánchez-Albornoz "como profesor a cargo de la cátedra de Historia de España” y “teniendo en cuenta las razones invocadas" -que serían seguramente la lejanía y la dificultad del traslado- aceptó la renuncia de éste para que fuese efectiva a partir del $1^{\circ}$ de mayo de $1956 .{ }^{45}$ Albornoz sería sustituido a la postre en la Cátedra por su propio hijo, Nicolás Sánchez-Albornoz, quien llegaría a convertirse en director del Instituto de Investigaciones Históricas de la Facultad. ${ }^{46}$

II 1952-1956, años cruciales: la génesis de España, un enigma histórico.

Trazado hasta donde es posible el camino que llevó a Sánchez-Albornoz de la Universidad Central de Madrid a la Universidad Nacional del Litoral, queda ahora el desafío de poner en valor la figura docente de medievalista español. Dicho de otra manera, habría que situarse ahora en el lugar de los alumnos de la Facultad de Filosofía, Letras y Educación de Rosario y preguntarse con ellos quién era ese profesor sexagenario que cada semana recorría 350 kilómetros para impartirles clase.

\footnotetext{
${ }^{43}$ Universidad Nacional del Litoral. Facultad de Filosofía, Letras y Ciencias de la Educación. Resolución N 1194. Rosario, 6 de abril de 1954. El documento señala: “Considerando que la mayoría de los alumnos aún no han rendido la asignatura Historia de España; que la referida cátedra estuvo a cargo del profesor Claudio Sánchez-Albornoz y que es de importancia para la Facultad, el contar con los servicios del prestigioso catedrático, el delegado interventor [...] resuelve: designar interinamente, a partir del 27 de abril y hasta el 28 de febrero de 1955, al profesor Doctor Claudio Sánchez-Albornoz para el dictado de la cátedra de Historia de España”. Mismos argumentos en las resoluciones número 1524 de $1^{\circ}$ de marzo de 1955 y número 1798 de 13 de marzo de 1956.

${ }^{44}$ Universidad Nacional del Litoral. Facultad de Filosofía, Letras y Ciencias de la Educación. Resolución N 1573. Rosario, 21 de abril de 1955. Documento en que la Decana de la Facultad, Erminda Benítez, "resuelve" pagar el sueldo no remunerado de Sánchez-Albornoz, titular de la Cátedra de Historia de España.

${ }^{45}$ Universidad Nacional del Litoral. Facultad de Filosofía, Letras y Ciencias de la Educación. Resolución N 1864. Rosario, 30 de abril de 1956.

46 "Sánchez-Albornoz y Aboín, Nicolás"; en Ignacio Peiró Martín y Gonzalo Pasamar Alzuria, (eds.), Diccionario Akal de historiadores españoles contemporáneos (1840-1980); op. cit.; 564-565.
}

167

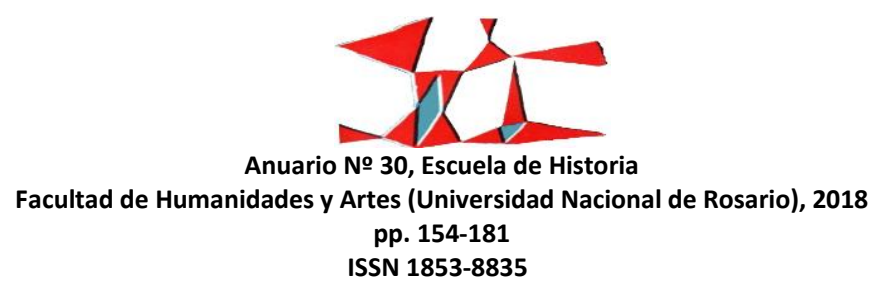


Sin duda, puede afirmarse que Sánchez-Albornoz era -junto con Ramón Menéndez Pidal, José Ortega y Gasset y Américo Castro- uno de los intelectuales españoles más destacados de su tiempo, uno de los políticos republicanos en el exilio más importante y el medievalista español con mayor reconocimiento internacional. Cuando pisó por vez primera las aulas de la Facultad rosarina su trayectoria docente era dilatada -más de tres décadas de trabajo en las aulas de distintas universidades le respaldaban-, tenía en su haber la fundación y dirección de dos de las revistas más prestigiosas del ámbito iberoamericano -el Anuario de Historia del Derechos Español (1924) y los Cuadernos de Historia de España (1944)- y sus aportes al mejor conocimiento de la alta Edad Media peninsular eran reconocidos por el medievalismo portugués, francés e italiano.

Ese reconocimiento se materializó en abril de 1953, cuando fue invitado por el Centro Italiano de Estudios Sobre el Alto Medioevo -con sede en la ciudad de Spoleto- a participar en las primeras jornadas que éste organizaba y que tenían como tema de discusión "El problema de la civilización carolingia". Nuestro medievalista aprovechó el viaje, que se extendió entre los meses de enero y mayo de aquel año, para impartir una serie conferencias en Burdeos y París, en tanto que en la jornada spoletina presentó una ponencia intitulada España y el medievalismo carolingio: ${ }^{47}$ "Resultó muy bien la semana carolingia de Spoleto -cuenta a su amigo Emilio Sáez meses después- y creo que los italianos recibieron mis teorías como base del origen del feudalismo europeo". ${ }^{48}$ El madrileño sería invitado en diversas ocasiones a la celebración de las jornadas del CISAM, las cuales se convertirían a la postre en una de las reuniones científicas más importantes del medievalismo europeo. En este sentido, el alumno que asistía a clases con Sánchez-Albornoz podía tener la seguridad de que tenía frente a sí a un estudioso que había compartido las inquietudes intelectuales y científicas de un Marc Bloch -quien le consideraba "amigo"-49 y que había llevado al medievalismo argentino

\footnotetext{
47 Sánchez-Albornoz, Claudio; "España y el feudalismo carolingio"; en I problemi della civilità carolingia. I Settimane di Studi Sull Alto Medioevo del CISAM, Centro Italiano di Studi sull Alto Medioevo; Spoleto, 1954; pp. 109-145. Reproducido en: Sánchez-Albornoz, Claudio; Estudios sobre las instituciones medievales españolas; Universidad Nacional Autónoma de México; México; 1965; pp. 765790; Sánchez-Albornoz, Claudio; Viejos y nuevos estudios sobre las instituciones medievales españolas, 3 vols.; Espasa-Calpe; Madrid; 1971; vol. II, pp. 1249-1276.

48 Sáez, "Epistolario [...] III (1952-1954)"; op. cit; p. 209.

49 La reproducción fotográfica de la carta en la que Marc Bloch le denomina de esta forma en : Maison des Sciences de l'Homme: Exposition. L'Espagne. Un énigme historique. Claudio Sánchez-Albornoz. Historien et Politique, Paris, 25 novembre - 22 décembre 1993, Fundación Sánchez-Albornoz - Maison des Sciences de I’Homme, París-Ávila, 1993, p. 118. Nicolás Sánchez-Albornoz ha reproducido la carta en su versión castellana: Sánchez-Albornoz, Nicolás; "La Fundación Rockefeller y los exilados españoles"; en Historia 16, Historia 16; Madrid; abril 1994; pp. 116-120; p. 18. Nosotros hemos transcrito la carta en el francés original y pronto será publicada: Ríos Saloma; “De Europa a América....", op. cit.
}

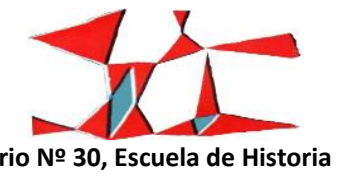




\section{Claudio Sánchez-Albornoz, profesor de la Universidad Nacional del Litoral (Rosario)1952-1956}

el método de trabajo de los seminarios de la escuela alemana y con ellos, el rigor y la erudición de una práctica de la disciplina histórica que se remontaba al último tercio del siglo XIX. Ello no debe hacer pensar, sin embargo, que Sánchez-Albornoz era simplemente heredero y representante de un arcaico positivismo; antes bien, era un historiador serio y riguroso que basaba sus interpretaciones en un minucioso análisis documental, pero que buscaba explicar los procesos y los cambios en el devenir histórico y en particular los cambios ocurridos en la península ibérica en la transición de la antigüedad al feudalismo.

Pero ese profesor consolidado, que bien habría podido limitarse a repetir sus lecciones aprendidas de memoria, además de poseer un acendrado amor por España y un patriotismo fuera de toda duda, era un lúcido e inquieto intelectual para quien la búsqueda de la verdad y la resolución de los problemas históricos que se le iban presentando en sus investigaciones era no sólo una obligación científica sino ética. Ello es lo que explica que a sus 55 años se lanzara a una nueva empresa intelectual detonada por la aparición del ensayo de Américo Castro, España en su historia: cristianos moros y judíos, publicado en Buenos Aires por la editorial Losada en 1948 y que daría como resultado la redacción de España, un enigma histórico, obra que resultó ser uno de los ensayos más importantes y difundidos sobre la historia española que se escribieron a mediados del siglo pasado. ${ }^{50}$

Es conocido por los especialistas el contenido de la obra de Castro, la respuesta de Sánchez-Albornoz, el debate que se mantuvo vigente sobre la historia y el ser de España a lo largo de más de una década y el encono personal entre dos antiguos amigos y dos de los intelectuales españoles más importantes del siglo XX como para tener que reproducir en este breve espacio elementos ya sabidos. Pero lo que no ha sido estudiado con detenimiento es, precisamente, la génesis -al forja material- de España, un enigma histórico. La elaboración de la obra por la que sería conocido Sánchez-Albornoz por el gran público de amabas orillas del Atlántico coincidió, precisamente, con los años de magisterio de Rosario y gracias a la correspondencia que el maestro español tuvo con el ya citado Emilio Sáez, así como a los documentos conservados en la biblioteca personal de don Claudio en Buenos Aires, es posible reconstruir el proceso de escritura de la misma.

Sánchez-Albornoz había tenido conocimiento de que Castro preparaba su obra a finales de 1947 con motivo de la nota que éste último le había dirigido desde Princeton agradeciéndole el envío de los dos tomos

\footnotetext{
${ }^{50}$ Castro; op. cit.; Sánchez-Albornoz; España, un enigma histórico..., op. cit. 169

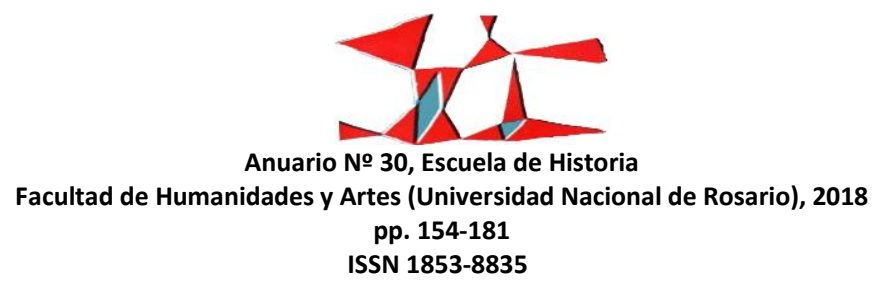


de su España musulmana. Castro señalaba en la nota, fechada el 15 de noviembre de 1947: "Feliz usted que ve en la calle el fruto de su trabajo. Losada tiene un libro desde abril de 1946 y no sé cuando saldrá. Cuanto me habría servido su nuevo monumento: en la edición inglesa le citaré". ${ }^{51}$

No cabe duda de que Sánchez-Albornoz se hizo con el original del libro de Américo Castro en cuanto éste se publicó, no sólo porque el autor era su amigo y por el hecho de que se editara en Buenos Aires, lo que facilitaba la compra, sino porque estaban interesados en los mismos problemas relativos a la forja del ser hispano y al sentido de la historia de España, particularmente de la historia reciente. El ejemplar de la obra de Castro se conserva en la biblioteca personal de don Claudio que se custodia en el Centro Argentino de Estudios Históricos "Claudio Sánchez-Albornoz" y se halla profusamente anotado en los márgenes, lo que demuestra una lectura atenta y despaciosa por parte del medievalista madrileño. Así, por ejemplo, ante la idea de Castro según la cual "el caballero español, por razones que irán apareciendo a lo largo de este libro, necesitaba rodearse de un halo de trascendencia, de un prestigio religioso, regio o de honra", SánchezAlbornoz escribe: "Nada de halo mágico, guerra en serio". ${ }^{52}$ Más adelante, cuando Castro habla sobre la situación de España en época visigoda y remite en la nota al pie al estudio que publicara Manuel Torres en el Anuario de Historia del Derecho Español sobre para profundizar en el estudio de "la estructura política del pueblo visigodo", ${ }^{33}$ Sánchez-Albornoz, que algo sabía del mundo visigodo y había fundado el Anuario exclama, indignado, “¿y mis gardingos?”, refiriéndose al capítulo que había publicado en sus Orígenes del feudalismo. ${ }^{54}$

La atenta lectura del texto de Castro generó en Sánchez-Albornoz un impulso de réplica que queda asentado en la carta que envió a Emilio Sáez con fecha de 3 de septiembre de 1949 en la que le informa de que "por fin" se había aprobado el presupuesto de la Universidad al que nos referíamos más arriba y añade: "Espero cobrar uno de estos días y enseguida le enviaré la obra de Américo. Voy a meterme con ella". ${ }^{55}$ Hasta

\footnotetext{
${ }^{51}$ Carta de Américo Castro a Claudio Sánchez-Albornoz, Princeton, Estados Unidos, 11 de noviembre de 1947. Universidad de Buenos Aires. Instituto de Historia de España. Caja "Notas y homenajes a don Claudio Sánchez-Albornoz", Clasificación N(18)/72. Documento sin catalogar. Habré de reproducir la nota en el artículo "Espejo de una vida: Claudio Sánchez-Albornoz y los Cuadernos de Historia de España (1944-1982)" que se encuentra actualmente en dictamen por parte de la revista Estudios de Historia de España de la Universidad Católica Argentina.

52 Castro, España en su historia..., op. cit., p. 34.

53 Torres, Manuel; “El estado visigótico"; en Anuario de Historia del Derecho, N³, Centro de Estudios Históricos; Madrid; 1926; pp. 307-475. La referencia a la obra de torres se encuentra en la página 46.

54 Sánchez-Albornoz, Claudio, "Fideles y gardingos en la monarquía visigoda. Raíces del vasallaje y del beneficio hispanos", en SánchezAlbornoz; En torno a los orígenes del feudalismo, op. cit.

55 Sáez, "Epistolario [...] I (1948-1949)"; op. cit., p. 214.
}

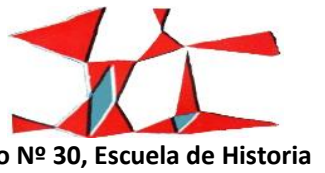




\section{Claudio Sánchez-Albornoz, profesor de la Universidad Nacional del Litoral (Rosario)1952-1956}

donde me ha sido posible averiguar, esta es la primera referencia que se conserva sobre la voluntad de réplica de don Claudio, voluntad que se iría materializando a lo largo del año siguiente, de tal suerte que nuestro historiador escribía el 3 de mayo de 1950 a Sáez: "Sigo con el anti Castro. Despacio, pues estoy muy cansado, las clases y el Instituto me cansan. No tengo buena salud". ${ }^{56} \mathrm{~A}$ principios del mes de junio Sánchez-Albornoz podía decir, ufano: "He escrito muchas páginas contra Castro. Voy a enviarlas a Ramos [Loscertales]. Puede V. leerlas. Le agradeceré la opinión. Pero no quiero se pierdan ni se divulguen. Aún no he acabado. He debido interrumpirlas por lo de Halphen. Trabajo muy mal y cansado. Estoy pasando una mala época de salud y de todo". ${ }^{57}$

A mediados de 1950 eran ya tantas las páginas escritas que Sánchez-Albornoz había decidido para entonces convertir su respuesta en un libro y así, el 29 de julio, en pleno invierno porteño, escribe a su corresponsal madrileño: "Recibe V. un segundo Américo. Estoy con el anti Américo en el telar. Será un libro. Ya lo enviaré a esa" ${ }^{58} \mathrm{~A}$ inicios de septiembre de aquel año Sánchez-Albornoz tuvo noticia por su amigo Ramos Loscertales de que en España había salido ya una primera réplica al libro de Castro - "un Anti-Castro", le llamade Pedro Laín Entralgo y pide a su amigo Sáez que, a su vez, solicite el ejemplar a Sánchez Cuesta, rogándole que se lo hagan llegar por avión: "necesito leerlo con urgencia -escribe el 6 de septiembre-. Sigo leyendo y trabajando en mi Anti-Castro. Lo voy a titular Mahoma en España o Castro convencido. Pero no lo divulgue para que no me lo pisen".$^{59}$ Un mes después, sin embargo, aún no había recibido el ejemplar de Laín. ${ }^{60}$ El 29 de diciembre, metido ya en pleno verano austral, nuestro medievalista volvía escribir, irónico y a tenor de los acontecimientos mundiales: "Un Américo del siglo XXX si pilla esta carta va a decir que yo padezco de un negativismo total y que indudablemente soy un converso. Esta salida le indica que sigo metido ahora con el Anti-Américo. A mediados del próximo mes quiero irme a Córdoba, me hace mucha falta". ${ }^{61}$

\footnotetext{
56 Sáez, Carlos, "Epistolario de Claudio Sánchez-Albornoz y Emilio Sáez II (1950-1951)"; Signo. Revista de historia de la cultura escrita; N 4; Universidad de Alcalá; Alcalá de Henares; 1997; pp. 273-289; p. 279.

57 Ibid., p. 280.

58 Ibid., p. 280.

59 Ibid., p. 282

60 lbid., p. 282

61 lbid., p. 285.
}

171

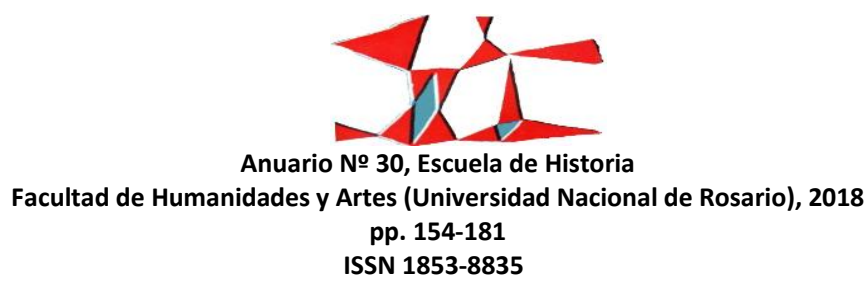


A fines de enero de 1951, dese la Sierra Córdoba, Sánchez-Albornoz anuncia a su amigo Sáez que escribiría "un libro par los chilenos" sobre las instituciones feudales de Castilla, ${ }^{62}$ pero sin saber cuándo, pues la obra sobre Castro seguía "en el telar". Consciente de que la crítica que preparaba sobre la obra de su amigo y compañero de exilio era contundente, concluye nuestro medievalista, metafórico: "Llegaremos a las manos". ${ }^{63}$ Para mayo de 1951, "el Anticastro" -juego de palabras con las que quería mostrar su rechazo a la obra del filólogo, a quien consideraba para entonces un "Anticristo"- le seguía ocupando "mucho tiempo". ${ }^{64}$ La conclusión de la obra se retrasó con motivo del inicio de sus actividades docentes en Rosario y del viaje que el profesor madrileño realizó a Chile en el mes de agosto, viaje en el que le homenajearon y en el que impartió diversas conferencias. ${ }^{65}$ Con todo, a finales de noviembre podía escribir de nuevo a Sáez: "Mi anticastro avanza, avanza, avanza, pero no llega nunca. Cada mes un capítulo nuevo. Va a ser una birria, o la octava maravilla del mundo. Modestia aparte, que naturalmente no tenemos los españoles y de la cual yo hago merced a todos los argentinos, que tampoco la tienen". ${ }^{66}$

Tras alguna referencia menor relativa al avance del trabajo sobre la obra de Castro realizada a lo largo de la primera mitad del año de 1952, ${ }^{67}$ el 16 de octubre de 1952 el medievalista madrileño convertido en profesor rosarino puede escribir a Sáez que su "Anti-Castro está acabándose" ${ }^{68}$ y darle una buena noticia nueve meses después, el 23 de julio de 1953: “Entre mi viaje a Europa y la operación de Delia ando muy retrasado de trabajo, pero ya tengo editor para mi anti-Castro. Lo va a publicar la Sudamericana y, Dios mediante, aparecerá a fin de año". ${ }^{69}$ Para el día 10 de septiembre de aquel mismo año de 1953, SánchezAlbornoz podía afirmar que el libro estaba "a punto de caramelo" y que "pronto empezar[ían] a imprimirlo", aunque el tono de la nota dejaba traslucir que la redacción de la réplica se hacía más larga y pesada de lo que en un principio se había imaginado. "Me tiene archiharto", sentencia. ${ }^{70}$

\footnotetext{
62 La obra aparecería dos décadas después: Sánchez-Albornoz, Claudio; Investigaciones y documentos sobre las instituciones hispanas; Editorial Jurídica de Chile; Santiago de Chile; 1970.

63 Sáez, "Epistolario [...] II (1950-1951)"; op. cit.; p. 285.

64 lbid., p. 286.

65 Ibid., p. 288.

66 Ibid., p. 289.

67 Sánchez-Albornoz puede escribir el 18 de junio: "El anticastro me absorbe los ratos libres de clases e Instituto. Quiero acabarlo de una vez y tengo este año el problema de la renovación de mi contrato". Sáez, "Epistolario [...] III (1952-1954)", op. cit., p. 206.

68 lbid., p. 207.

69 Ibid., p. 209.

70 lbid., p. 210.
}

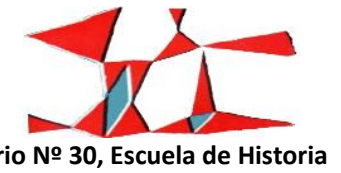




\section{Claudio Sánchez-Albornoz, profesor de la Universidad Nacional del Litoral (Rosario)1952-1956}

Como era de esperar, la conclusión del libro tardaba más de lo deseado tanto por la profundidad de la respuesta como por el poco tiempo libre que le dejaban sus actividades docentes en Buenos Aires y Rosario pero don Claudio dedicó todos sus esfuerzos a terminarlo, al menos a partir de la segunda mitad del año de 1954: "Tiene razón de quejarse de mi silencio epistolar -escribe Sánchez-Albornoz a Sáez el $1^{\circ}$ de octubre-. Perdóneme. No escribo a nadie. Ni a mis hijas. Estoy deseando entregar a la imprenta el anti-Castro. Lo releo y corrijo ahora, con ayuda de Dios lo entregaré a la imprenta en unas semanas. Me falta tiempo". ${ }^{71}$ Tras semanas de actividad febril, el 27 de diciembre de ese mismo año, en plena primavera porteña, el madrileño informa con júbilo a Saéz: "Ya está terminado el Anti-Castro. No sé qué prisa se dará la editorial. Ha salido muy largo". ${ }^{72}$ La editorial Sudamericana ciertamente se dio prisa en las labores de maquetación, pues a finales de junio de 1955 Sánchez-Albornoz se hallaba "corrigiendo pruebas" de su libro, un libro que a en principio y debido al volumen aparecería en tres tomos: "ya he corregido las galeras del primer tomo, pero me queda todavía una gran cuesta arriba que subir. No sé cuando saldrá. Imagino que la editorial querrá vender a un mismo tiempo los tres tomos. He procurado evitar toda intención política en el libro, pero no sé si va a entusiasmar en esas latitudes". ${ }^{73}$

La historia, siempre incierta, quiso sin embargo que los bombardeos de la Plaza de Mayo de 16 de junio de aquel 1955 y el posterior golpe de estado contra el gobierno de Perón del 16 de septiembre -“dos revoluciones" bajo la óptica del medievalista español que serían en realidad dos episodios que conformaron el inicio del golpe de estado de la auto-proclamada "revolución libertadora"- impidieran la aparición del libro. Merece la pena abrir un paréntesis a propósito de estos episodios para señalar que Sánchez-Albornoz no se sentía cómodo bajo el régimen de Perón y afirmaba que "era ya irrespirable la atmósfera en Buenos Aires", al tiempo que agradecía en su correspondencia personal a Sáez el apoyo que le había brindado durante los momentos de mayor tensión José Luis Romero, antiguo miembro del Instituto, colaborador de los Cuadernos y a la sazón Rector de la Universidad de Buenos Aires. La situación política era tan difícil e inestable que el antiguo embajador sentía que se vería obligado de nuevo obligado a exiliarse y había llegado a contemplar, incluso, Venezuela como eventual país de residencia. "Todas estas inquietudes -concluye- han hecho retrasar la aparición de mi libro. Ya no saldrá hasta marzo. Pero estoy contento porque saldrá bien. Con la baja del

\footnotetext{
71 Ibid., p. 214.

72 Ibid., p. 215.

73 Sáez, Carlos, "Epistolario de Claudio Sánchez-Albornoz y Emilio Sáez IV (1955-1958)"; en Signo. Revista de historia de la cultura escrita; N 7; Universidad de Alcalá; Alcalá de Henares; 2000; pp. 159-180; p. 164.
}

173

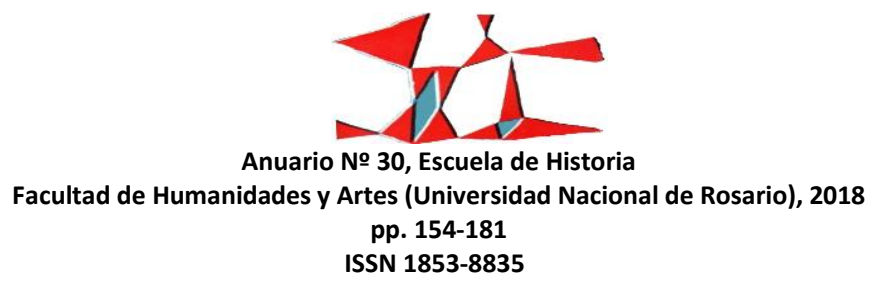


peso podrá venderse barato en España". ${ }^{74}$ El libro, sin embargo, no salió en marzo y nuestro autor testimoniaba el 22 de mayo de 1956 "la conclusión de pruebas de [su] anti-castro" y suponía que saldría "en un par de meses", resignado y haciéndose eco del viejo refrán castellano según el cual "las cosas de palacio van despacio". 75

Las conmociones políticas de la república argentina se traducirían en ese mismo año de 1956 en otro sinsabor intelectual para don Claudio. A principios de noviembre estalló una huelga general del sector gráfico y con fecha del 21 de dicho mes Sánchez-Albornoz escribía a Sáez: "Llevamos 10 días de huelga total de gráficos. De no haber estallado estaría ya mi libro en la calle. Nada se sabe de la terminación del conflicto gremial y no puedo calcular ya cuando aparecerá mi obra. Le enviaré un ejemplar y espero que dé noticia de él en alguna revista española". ${ }^{76} \mathrm{Y}$, para añadir dramatismo al asunto, en una carta redactada entre finales de noviembre y los primeros días de diciembre, Sánchez-Albornoz se lamenta amargamente: "La huelga de gráficos no ha terminado aún. Acabó la de los obreros que trabajaban y trabajan en los periódicos. La otra lleva un mes y no tiene aire de terminar. Ya no es cuestión de salarios sino de orgullo patronal y sindical. Ya ni me acuerdo de mi libro. Sólo Alá sabe cuándo saldrá. Por ocho días me pilló el carro. Mala suerte y paciencia. El editor está desesperado. Yo no porque estoy acostumbrado a los palos. iCon tal de que no arda la imprenta!". ${ }^{77}$ La fortuna quiso que la imprenta no ardiera y que España, un enigma histórico, titulo que finalmente recibió la magna obra del antiguo rector de la Universidad de Madrid, se acabase de imprimir según consta en el colofón- "el día treinta y uno de diciembre de mil novecientos cincuenta y seis". ${ }^{78}$ Desde el $1^{\circ}$ de mayo ese año, don Claudio había renunciado a sus clases en la Universidad Nacional del Litoral.

Mientras Sánchez-Albornoz convertía su réplica en libro, tuvo noticia en algún momento de 1952 de que Américo Castro, "sin esperar a que se ago[tara] la primera edición de España en su historia" preparaba ya "la próxima publicación de un nuevo texto de su obra magnífica" en la que introducía "grandes novedades". Consciente de que la respuesta que redactaba tenía aún mucho trabajo por delante y preocupado de que las ideas de su amigo literato circulasen libremente y sin crítica, nuestro medievalista optó por realizar una

\footnotetext{
74 lbid., p. 165.

75 lbid., p. 166.

76 Ibid., p. 168.

77 Ibid., p. 169.

78 Sánchez-Albornoz, España, un enigma histórico..., op. cit. Colofón. Tomo II.
}

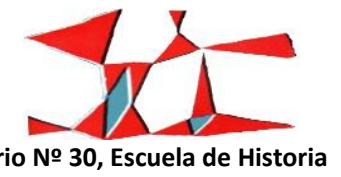




\section{Claudio Sánchez-Albornoz, profesor de la Universidad Nacional del Litoral (Rosario)1952-1956}

primera réplica científica, respetuosa por lo demás, que apareció en la sección Miscelánea del número XIX (1953) de los Cuadernos de Historia de España bajo el título “Ante España en su historia”. ${ }^{79}$

Este largo comentario resulta interesante desde la perspectiva teórica, metodológica, historiográfica e interpretativa, las cuales tendremos ocasión de abordar en otro momento. Sin embargo, para la historia que venimos reconstruyendo, lo que quisiéramos destacar es, por una parte, que este primera crítica sobre la obra de Castro -y que desataría en realidad el debate posterior- fue redactado cuando Sánchez-Alborno ejercía ya como docente en Rosario; por la otra, que el título de la que sería la gran obra editada en 1956 se anunciaba en realidad en este primer trabajo: “He anunciado -afirma- más de una vez la inmediata aparición de mi interpretación personal del enigma histórico de España. Es notorio que me lancé a la atrevidísima aventura de investigar y meditar en torno a esa siempre viva cuestión llevado de mi disentimiento frente a la obra de Castro. He reflexionado mucho sobre ésta". ${ }^{80}$ En una segunda crítica al pensamiento de Castro aparecida en 1954 en el número XXI-XXII de los Cuadernos de España bajo el título "Ensayo de historiología", Sánchez-Albornoz anunciaría, por fin, el título definitivo que llevaría el texto sobre el que estaba trabajando: "He de enfrentar en mi obra, España, un enigma histórico, próxima a parecer, -asegura- la teoría historiográfica defendida en el estudio que motiva estas líneas, apostilla en franca retirada, inconfesa, de España en su historia. No voy por ello a comentar aquí su tesis. Me interesa sólo contradecir una de sus afirmaciones".$^{81}$

Antes de concluir, quisiéramos detenernos en una serie de datos importantes que permiten calibrar la importancia que tuvieron los años 1951-1956 en la trayectoria intelectual del antiguo embajador republicano. Al acercarse a España, un enigma histórico, el lector puede constatar que se trata de un ensayo de largo aliento y no sólo por sus cientos de páginas. Lo que proponía Sánchez-Albornoz era una interpretación bajo la óptica de larga duración -¿qué otra cosa podía significar remitirse a "la España primitiva" y concluir con el "cortocircuito de la modernidad española"?- sobre el pasado de España. Una reflexión que no sólo se basaba en el magnífico conocimiento del autor de los archivos peninsulares, de las fuentes y de los debates historiográficos de su tiempo, sino, ante todo, en la perspectiva de análisis que

\footnotetext{
79 Sánchez-Albornoz, Claudio; “Ante España en su Historia”; en Cuadernos de Historia de España; № 19; Instituto de Historia de España; 1953; pp. 129-145.

80 Ibid., p. 129.

81 Sánchez-Albornoz, Claudio; “Ensayo de historiología”; en Cuadernos de Historia de España; № 20-21; Instituto de Historia de España; 1954; pp. 380-382.
}

175

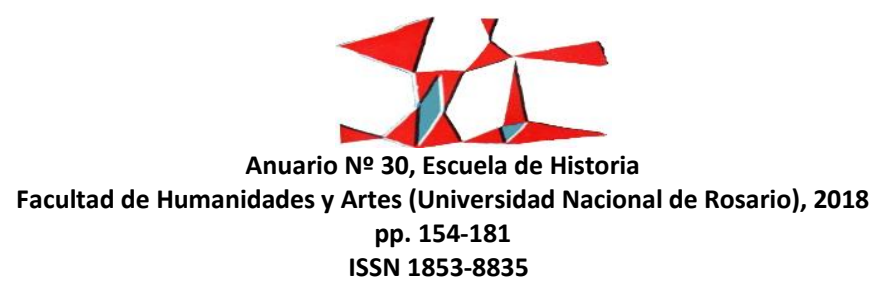


generó su condición de exiliado en Argentina, condición que le permitió situarse en una doble distancia geográfica y epistemológica- desde la cual lanzar miradas hacia la patria lejana y hacia su pasado.

Es de sobra conocido el hecho de que Fernand Braudel concibió su estudio sobre el Mediterráneo a partir de su experiencia brasileña y el estudioso de la obra albornociana podría intuir en el trasfondo de España, un enigma histórico, ecos de la obra braudeliana. Pero existen una serie de datos que, puestos en relación, permiten afirmar que la obra cumbre de don Claudio se inspiró en la obra de Braudel. En la biblioteca personal de Sánchez-Albornoz en Buenos Aires se conserva el ejemplar de la primera edición en castellano de El Mediterráneo y el mundo mediterráneo en la época de Felipe Il realizada por el Fondo de Cultura Económica. Publicado originalmente en francés en 1949 -un año después que España en su historia de Castro-, la obra fue traducida en 1953 al castellano por la editorial mexicana. ${ }^{82}$ El destino quiso que entre las páginas del libro de Américo Castro La realidad histórica de España de la biblioteca personal de Sánchez-Albornoz se conservara entre las páginas 620 y 621 la nota de compra del libro de Braudel expedida por la "librería del Colegio", que lleva la fecha del 20 de julio de 1954, fecha que coincide con la redacción de la obra albornociana. ${ }^{83}$ Es lícito suponer que la aparición de la nueva versión de la obra de Castro a la que SánchezAlbornoz hacía alusión en el número XIX de los Cuadernos espoleara al madrileño para dar aún mayor solidez a su crítica a las tesis de Castro y que encontrara en el Mediterráneo no sólo datos y argumentos históricos, sino una amplia perspectiva histórica: al comparar los índices de ambos textos, por ejemplo, el lector puede comprobar que la obra del historiador español se abre -tras las consideraciones de orden historiográfico- con un capítulo sobre las condiciones geográficas de la península ibérica intitulado "La tierra y el hombre en España". ${ }^{84}$

\section{Conclusiones}

\footnotetext{
82 Braudel, Fernand, La Méditerranée et le Monde méditerranéen à l'époque de Philippe II; Gallimard; París; 1949. Versión castellana: El Mediterráneo y el mundo mediterráneo en la época de Felipe II, 2 vols., Fondo de Cultura Económica; México; 1953. Sobre Braudel y la forja de El Mediterráneo: Dax, Pierre; Braudel; Flammarion; París; 1995, en especial el capítulo IV, pp. 109-136.

83 Castro, Américo, La realidad histórica de España; Porrúa; México; 1954.

${ }^{84}$ Sánchez-Albornoz, Claudio, España, un enigma histórico, op. cit., pp. 72-98. No puede soslayarse el hecho de que las Historias generales de España, desde la de Florián de Ocampo hasta la de Miguel Morayta se abren siempre con una descripción geográfica, pero me parece que en el caso concreto de Sánchez-Albornoz se trata de una perspectiva distinta, braudeliana, marcada por la relación de los hombres con el medio.
}

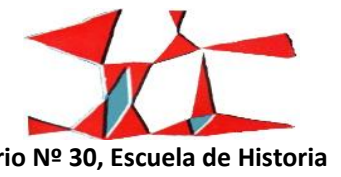




\section{Claudio Sánchez-Albornoz, profesor de la Universidad Nacional del Litoral (Rosario)1952-1956}

A lo largo de estas páginas hemos reconstruido diversos momentos de la trayectoria personal e intelectual del medievalista español Claudio Sánchez-Albornoz siguiendo dos caminos paralelos que confluyen en la ciudad de Rosario en el periodo 1952-1956. Por un lado, hemos repasado los hechos que llevaron al madrileño de la Universidad Central de Madrid a la Universidad del Litoral y la forma en que la siempre precaria situación económica, conjugada con su decisión de echar raíces en Argentina, le llevaron a aceptar un ejercicio docente que le resultaba cuanto menos fatigoso. Por el otro, hemos analizado como la realidad del exilio le permitió constatar en el continente americano la proyección de las experiencias históricas y culturales hispanas forjadas a lo largo de los siglos medievales y plantear, en consecuencia, la institucionalización en las universidades argentinas de la enseñanza de la historia de España como vía para comprender un pasado común.

En el marco de esta trayectoria vital e intelectual, el libro de Américo Castro se convirtió en el detonante de una profunda reflexión de naturaleza histórica e historiográfica que se materializaría en la elaboración de España, un enigma histórico, elaboración que coincidió con el desempeño docente de quien sería considerado "como el patriarca de la Historiografía española y maestro incuestionable de los medievalistas hispanos". ${ }^{85}$ Hemos recorrido detalladamente la cronología de la escritura de la magna obra de Sánchez-Albornoz y hemos intuido los vínculos intelectuales entre éste y la historiografía de los Annales. Es plausible lanzar la hipótesis de que Sánchez-Albornoz pudiera haber conocido a Braudel durante su viaje a París en el invierno de 1953 -en algún momento muy posterior se referiría a él como "el gran historiador Braudel" 86 . De lo que no se puede dudar es de que el profesor de la Facultad de Filosofía, Letras y Educación Universidad Nacional del Litoral conocía la obra cumbre de Braudel, de que mostraba a sus sesenta años una firme voluntad de mantenerse actualizado y de que los vínculos y relaciones intelectuales entre España, un enigma histórico y el Mediterráneo son cercanas y están aún por explorar.

\section{BIBLIOGRAFÍA}

\footnotetext{
85 Sánchez-Albornoz, Claudio, Mis tres primeros estudios históricos (Iniciación de una vocación), Universidad de Valladolid, Valladolid, 1974. La ponderación de la figura de don Claudio se encuentra en la solapa.

86 Sánchez-Albornoz, Claudio; "Dos comentarios"; en Cuadernos de Historia de España; №33-34; Instituto de Historia de España; Buenos Aires; 1961; pp. 314-335, p. 331, nota 18.
}

177

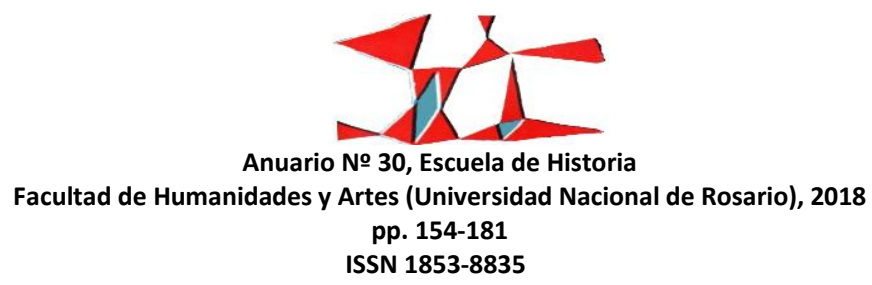


AA. VV; Sánchez-Albornoz a debate. Homenaje de la Universidad de Valladolid con motivo de su centenario; Universidad de Valladolid; Valladolid; 1993

Ballent, Anahi; Las huellas de la política, Vivienda, ciudad, peronismo, Universidad de Quilmes-Prometeo; Buenos Aires; 2005.

Braudel, Fernand, La Méditerranée et le Monde méditerranéen à l'époque de Philippe II; Gallimard; París; 1949.

Braudel, Fernand; El Mediterráneo y el mundo mediterráneo en la época de Felipe II, 2 vols., Fondo de Cultura Económica; México; 1953.

Cabeza de Sánchez-Albornoz, Sonsoles; Semblanza histórico política de Claudio Sánchez-Albornoz; Fundación Universitaria Española-Diputación Provincial de León; León; 1992.

Dax, Pierre; Braudel; Flammarion; París; 1995.

Guiance, Ariel; "La historiografía española y el medievalismo americano: Sánchez-Albornoz, Américo Castro y la construcción de la identidad nacional a través de la Edad Media"; en Ariel Guiance (dir.); La influencia de la historiografía española en la producción americana; Marcial Pons - Instituto de Historia Simancas; Madrid; 2011; pp. 25-58.

Grassotti, Hilda; "Historia de un historiador"; en Homenaje al profesor Claudio Sánchez Albornoz, Universidad de Buenos Aires; Buenos Aires; 1964; pp. 13-27.

López Sánchez, José María; Los refugios de la derrota. El exilio científico e intelectual republicano de 1939; Consejo Superior de Investigaciones Científicas; Madrid; 2013.

Maison des Sciences de l'Homme: Exposition. L'Espagne. Un énigme historique. Claudio Sánchez-Albornoz. Historien et Politique, Paris, 25 novembre - 22 décembre 1993, Fundación Sánchez-Albornoz - Maison des Sciences de l'Homme, París-Ávila, 1993.

Martín, José Luis; “Claudio Sánchez-Albornoz (1893-1984)”; en J. Aurell y F. Crosas (eds.); Rewriting the Middle Ages in the Twenthiet Century; Brépols; Turnhout; 2005; pp. 149-170.

Castro, Américo, España en su historia: cristianos, moros y judíos; Losada; Buenos Aires; 1948.

Pastor de Togneri, Reyna; "Claudio Sánchez-Albornoz y sus claves de la historia medieval de España”; en E. Sarasa y E. Serrano (coords.); Historiadores de la España medieval y moderna, número especial de la Revista de historia Jerónimo de Zurita; N 73; CSIC; Zaragoza; 1998; pp. 117-131

Peiró Martín, Ignacio y Pasamar Alzuria, Gonzalo (eds.); Diccionario Akal de historiadores españoles contemporáneos (1840-1980); Akal; Madrid; 2002. 


\section{Claudio Sánchez-Albornoz, profesor de la Universidad Nacional del Litoral (Rosario)1952-1956}

Pérez-Prendes y Muñoz de Arraco, José Manuel; "Semblanza y obra de don Claudio Sánchez-Albornoz"; En la España medieval; N5; Facultad de Geografía e Historia; Madrid; 1986, pp. 19-52.

Pilcic, Talía; "La distribución del bienestar en la Argentina Peronista. La ley de Propiedad Horizontal y su impacto en la ciudad de Mar del Plata"; en Segundas Jornadas Nacionales de Historia Social, 13, 14 y 15 de mayo de 2009, La Falda, Córdoba. Memoria Académica; Universidad de la Plata; La Plata; 2009 Disponible en: http://www.memoria.fahce.unlp.edu.ar/trab eventos/ev.9748/ev.9748.pdf

Principado de Asturias; Homenaje de Asturias a Claudio Sánchez-Albornoz; Caja de Ahorros de Asturias; Oviedo; 1980.

Real Academia de la Historia, "Acta de la Junta Pública del domingo 28 de febrero de 1926 con motivo de la recepción de Claudio Sánchez-Albornoz"; en Boletín de la Real Academia de la Historia; N LXXXVIII; Real Academia de la Historia; Madrid; 1926; pp. 376-378.

Ríos Saloma, Martín; "De Europa a América: Claudio Sánchez-Albornoz y la fundación de los Cuadernos de Historia de España"; en Medievalismo, N²8; Sociedad Española de Estudios Medievales; Madrid; 2018. En prensa.

Sáez, Carlos; "Epistolario de Claudio Sánchez-Albornoz y Emilio Sáez I (1948-1949)"; en Signo. Revista de historia de la cultura escrita; º3; Universidad de Alcalá; Alcalá de Henares; 1996; pp. 205-220.

Sáez, Carlos, "Epistolario de Claudio Sánchez-Albornoz y Emilio Sáez II (1950-1951)"; Signo. Revista de historia de la cultura escrita; N 4; Universidad de Alcalá; Alcalá de Henares; 1997; pp. 273-289.

Sáez, Carlos; "Epistolario de Claudio Sánchez-Albornoz y Emilio Sáez III (1952-1954)"; en Signo. Revista de historia de la cultura escrita; º 5; Universidad de Alcalá; Alcalá de Henares; 1998; pp. 203-215.

Sáez, Carlos, "Epistolario de Claudio Sánchez-Albornoz y Emilio Sáez IV (1955-1958)"; en Signo. Revista de historia de la cultura escrita; № 7; Universidad de Alcalá; Alcalá de Henares; 2000; pp. 159-180.

Sánchez-Albornoz, Claudio; "La potestad real y los señoríos en Asturias, León y Castilla"; en Revista de Archivos Bibliotecas y Museos; № 21; Madrid; 1914; pp. 263-293.

Sánchez-Albornoz, Claudio; Los orígenes del feudalismo; 3 vols.; Universidad Nacional de Cuyo; Mendoza; 1942.

Sánchez-Albornoz, Claudio; De Carlomagno a Roosevelt; Emecé; Buenos Aires; 1943.

Sánchez-Albornoz, Claudio; "Varia”; en Cuadernos de Historia de España; N 9; Instituto de Historia de España; Buenos Aires; 1948.

Sánchez-Albornoz, Claudio; “Ante España en su Historia"; en Cuadernos de Historia de España; № 19; Instituto de Historia de España; 1953; pp. 129-145.

179

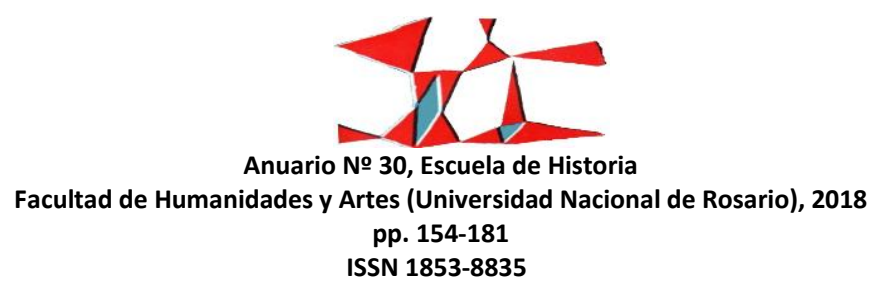


Sánchez-Albornoz, Claudio; "España y el feudalismo carolingio"; en I problemi della civilità carolingia. I Settimane di Studi Sull Alto Medioevo del CISAM, Centro Italiano di Studi sull Alto Medioevo; Spoleto, 1954; pp. 109-145.

Sánchez-Albornoz, Claudio; “Ensayo de historiología”; en Cuadernos de Historia de España; № 20-21; Instituto de Historia de España; 1954; pp. 380-382.

Sánchez-Albornoz, Claudio; España, un enigma histórico 2 vols.; Sudamericana; Buenos Aires; 1956.

Sánchez-Albornoz, Claudio; "Dos comentarios"; en Cuadernos de Historia de España; N 33-34; Instituto de Historia de España; Buenos Aires; 1961; pp. 314-335

Sánchez-Albornoz, Claudio; Estudios sobre las instituciones medievales españolas; Universidad Nacional Autónoma de México; México; 1965.

Sánchez-Albornoz, Claudio; Investigaciones y documentos sobre las instituciones hispanas; Editorial Jurídica de Chile; Santiago de Chile; 1970.

Sánchez-Albornoz, Claudio, Ensayos sobre historia de España; Siglo XXI; Madrid; 1973.

Sánchez-Albornoz, Claudio; Viejos y nuevos estudios sobre las instituciones medievales españolas, 3 vols.; Espasa-Calpe; Madrid; 1971.

Sánchez-Albornoz, Claudio; Mis tres primeros ensayos históricos; Universidad de Valladolid; Valladolid; 1976.

Sánchez-Albornoz, Claudio; Del ayer y del hoy de España; Planeta; Madrid; 1980.

Sánchez-Albornoz, Claudio, Postrimerías. Del pasado hacia el futuro; Planeta; Barcelona; 1981.

Sánchez-Albornoz; Claudio; Todavía. Otra vez de ayer y de hoy; Planeta; Barcelona, 1982.

Sánchez-Albornoz, Nicolás; "La Fundación Rockefeller y los exilados españoles"; en Historia 16, Historia 16; Madrid; abril 1994; pp. 116-120.

Sánchez Bella, Ismael; La vida cultural española en los últimos diez años; Universidad Nacional del LitoralInstituto Social; Santa Fe; 1952.

Torres, Manuel; "El estado visigótico"; en Anuario de Historia del Derecho,; N³; Centro de Estudios Históricos; Madrid; 1926; pp. 307-475.

Universidad Nacional de Cuyo; Memoria histórica de la Facultad de Filosofía y Letras (1939-1964); Universidad Nacional de Cuyo-Facultad de Filosofía y Letras; Mendoza; 1965.

Recibido: 3 de Julio de 2018 
Aceptado: 31 de Agosto de 2018

Versión Final: 18 de octubre de 2018

181

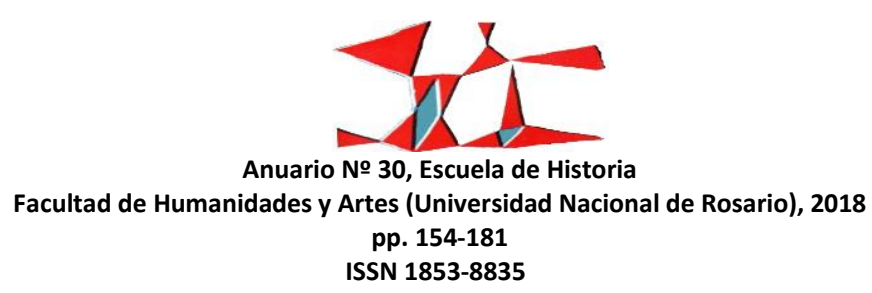

